\title{
Glial cell-line-derived neurotropic factor and its receptors are expressed by germinal and somatic cells of the rat testis
}

\author{
Sophie Fouchécourt, Murielle Godet, Odile Sabido ${ }^{1}$ and Philippe Durand \\ INSERM U 418; INRA UMR 1245; Université Claude-Bernard Lyon 1, 29 rue Sœur Bouvier, 69322 Lyon Cedex 05, France \\ ${ }^{1}$ Faculté de Médécine, Centre Commun de Cytométrie en Flux, Université Jean Monnet, 42023 St Etienne, France \\ (Requests for offprints should be addressed to P Durand; Email: durand@lyon.inserm.fr)
}

\begin{abstract}
Glial cell-line-derived neurotropic factor (GDNF) and its receptors glial cell-line-derived neurotropic factor $\alpha($ GFR $1 \alpha)$ and rearranged during transformation (RET) have been localized in the rat testis during postnatal development. The three mRNAs, and GDNF and GFR $1 \alpha$ proteins were detected in testis extracts from 1- to 90-day-old rats by reverse transcriptase PCR and Western blotting respectively. The three mRNAs were present in Sertoli cells from 20- and 55-day-old rats, pachytene spermatocytes (PS), and round spermatids (RS). The GDNF and GFR $1 \alpha$ proteins were detected in PS, RS, and Sertoli cells. GDNF and GFR $1 \alpha$ were also detected using flow cytometry in spermatogonia and preleptotene spermatocytes, and in secondary spermatocytes. The localization of GDNF and GFR $1 \alpha$ in germ and Sertoli cells was confirmed by immunocytochemistry. The hypothesis
\end{abstract}

that GDNF may control DNA synthesis of Sertoli cells and/or spermatogonia in the immature rat was addressed using cultures of seminiferous tubules from 7- to 8-day-old rats. Addition of GDNF for $48 \mathrm{~h}$ resulted in a twofold decrease in the percentage of spermatogonia able to duplicate DNA, whereas Sertoli cells were not affected. These results are consistent with a role of GDNF in inhibiting the S-phase entrance of a large subset of differentiated type A spermatogonia, together with an enhancing effect of the factor on a small population of undifferentiated (stem cells) spermatogonia. Moreover, the wide temporal and spatial expression of GDNF and its receptors in the rat testis suggest that it might act at several stages of spermatogenesis.

Journal of Endocrinology (2006) 190, 59-71

\section{Introduction}

Spermatogenesis is under the dual control of pituitary gonadotropins and local factors. Follicle-stimulating hormone (FSH) controls the Sertoli cells, which provide structural and nutritional support for the germ cells, and luteinizing hormone controls the production of testosterone by the Leydig cells (Russell et al. 1987). Local regulation involves intercellular communications between germ and Sertoli cells, and between Sertoli, myoid, and interstitial Leydig cells through growth factors, including neurotropic factors such as glial cell-line-derived neurotropic factor (GDNF; for review, see Parvinen \& Ventela 1999).

GDNF and neurturin, artemin and persephin are transforming growth factor $\beta$-related neurotropic factors acting via the same high-affinity receptor, the rearranged during transformation (RET) receptor tyrosine kinase. The signaling receptor complex also includes glycosylphosphatidylinositollinked co-receptors, the GDNF family receptor as: glial cellline-derived neurotropic factor receptor $\alpha(\operatorname{GFR} \alpha)$ 1-4. GFR $1 \alpha$ specifically binds to GDNF and mediates activation of the RET receptor (Jing et al. 1996). GDNF has been observed in a number of different cell types and structures of the central nervous system (Du \& Dreyfus 2002), where it stimulates neuronal survival and growth (Heuckeroth et al. 1988, Wang et al. 2002) and modulates synaptic plasticity (Ribchester et al. 1998). GDNF transcripts are also present in non-central nervous system and peripheral organs including the kidneys, lungs, blood, and testes (Suter-Crazzolara \& Unsicker 1994, Trupp et al. 1995, Suvanto et al. 1996).

Although fertile, gene-targeted mice with one GDNF-null allele show depletion of the reserve of stem cells, whereas mice overexpressing GDNF in the testis are infertile and accumulate undifferentiated spermatogonia (Meng et al. 2000). These results indicate that GDNF should contribute to the paracrine regulation of spermatogonial self-renewal, differentiation, and/or survival in the mouse. Moreover, since GDNFoverexpressing mice develop testicular tumors on aging, GDNF and its receptors GFR1 $1 \alpha /$ RET might have a role in the etiology of some testicular cancers (Meng et al. 2001). However, transgenesis experiments provide little information about the effect of GDNF on differentiated spermatogonia and no information on the possible involvement of this factor on later steps of spermatogenesis. 
Because of the potential importance of the GDNF/RET pathway in male reproductive physiopathology, we determined the localization of GDNF and its two receptors, GFR $1 \alpha$ and RET, during postnatal development of the rat testis. We determined mRNA and protein levels in isolated Sertoli and spermatogenic cells and also used cultures of seminiferous tubules from 7- to 8-day-old rats to examine the effect of GDNF on DNA synthesis by Sertoli cells and type A spermatogonia.

\section{Materials and Methods}

\section{Reagents and chemicals}

Trizol reagent, restriction enzymes, and Moloney murine leukemia virus (M-MLV) reverse transcriptase (RT) were purchased from Invitrogen SARL, pGEM-T Vector System from Promega, $p d(N)_{6}$ random hexamer from Amersham Biosciences Europe Group, DNA polymerase from Eurobio (Les Ulis, France), Qiagen Midi kit from Qiagen SA, polyacrylamide and other electrophoresis reagents were from BioRad Life Sciences Group, and nitrocellulose membrane from Schleicher and Schuell (Mantes-la-Ville, France). BCA kit was from Pierce (Perbio Science France, Bezons, France). ECL Plus Western Blotting Detection System was from Amersham Biosciences Europe Group. Collagenase was from Serva (Paris, France) and DMEM/ NUT MIX F12 culture medium from Invitrogen SARL. Recombinant GDNF was purchased from PeproTech, Inc. (Tebu-bio, Le Perray-en-Yvelines, France). DakoCytomation SA (Trappes, France) provided anti-vimentin monoclonal and anti-bromodeoxyuridine (BrdU) monoclonal and secondary antibodies, normal serum, and the streptavidine-horseradish peroxidase (HRP) detection system. Anti-GDNF goat polyclonal antibody was from R\&D Systems Europe (Lille, France), anti-GFR $1 \alpha$ monoclonal antibody from BD Biosciences (Le Pont-de-Claix, France) and anti-RET antibody (rabbit serum) was produced and characterized by Pelet et al. (1998). All other products were purchased from Sigma-Aldrich.

\section{Animals}

Male Sprague-Dawley rats ranging from 1 to 90 days (adult) of age were used. All procedures were approved by the Scientific Research Agency (Approval No. 69306) and conducted in accordance with the guidelines for care and use of laboratory animals.

\section{Preparation of Sertoli and germinal cell fractions}

Sertoli cells were obtained by collagenase digestion using 20- or 55-day-old rat testes (Weiss et al. 1997). The number of contaminating germ cells was reduced to a very low level (about $10 \%$ ) by several cycles of fragmentation of the cell clusters through a 19-gauge syringe needle, followed by sedimentation. Vimentin immunoreactivity was used to determine the percentage of germ cells (vimentin negative) contaminating the (vimentin positive) Sertoli cell preparations (Franke et al. 1979, Suter et al. 1997, Kopecky et al. 2005). An aliquot of each Sertoli cell preparation was cytospun onto aminoalkylsilanized slides. The cells were fixed in Bouin's solution, and rinsed twice with ethanol (70\%), then once with $\mathrm{NaCl} 9 \%$. Cell membranes were permeabilized with $0 \cdot 03 \%$ Triton X-100. An anti-vimentin specific monoclonal antibody was used at a dilution of 1:1000. Vimentin immunoreactivity was revealed by a biotin-coupled goat anti-mouse antibody incubated with streptavidinecoupled HRP giving a brown coloration to the Sertoli cells after reaction with diaminobenzidine (DAB). The cell nuclei were then stained with hematoxylin. The percentage of vimentin-negative cells in the Sertoli cell preparations was (mean \pm s.e.m.) $11 \pm 1$ and $8 \pm 1 \%$ in 20 -and 55 -day-old rats respectively $(n=3)$. Pachytene spermatocytes (PS) and round spermatids (RS) were obtained by centrifugal elutriation as previously described (Onoda et al. 1991, Weiss et al. 1997). Early and middle to late PS were recovered from 90-day-old rat testes, whereas early and middle PS were recovered from 22-day-old rat testes (Godet et al. 2000). The purity of the PS and RS fractions was assessed by flow cytometry (see below); $94 \pm 3 \%$ of the cells in the PS fractions were $4 \mathrm{C}$ cells, $3 \pm 2 \%$ were $2 \mathrm{C}$ cells and $1 \pm 0 \cdot 5 \%$ were $1 \mathrm{C}$ cells $(n=5)$. In the RS fractions, $81 \pm 2 \%$ of cells were $1 \mathrm{C}$ cells, $5 \pm 1 \%$ were $2 \mathrm{C}$ cells, and $10 \pm 2 \%$ were $4 \mathrm{C}$ cells $(n=3)$. Cell fractions were frozen until processed.

\section{Culture of seminiferous tubule segments from 7- to 8-day-old rats and $\mathrm{BrdU}$ incorporation}

At 7-8 days of age, the only germ cells are type A spermatogonia, since the first B spermatogonia do not develop until 11 days of age (Boitani et al. 1993, Dym et al. 1995, Jahnukainen et al. 2004). Culture of seminiferous tubule segments was performed as previously described for 21-dayold rat seminiferous tubules (Hue et al. 1998, Staub et al. 2000, Perrard et al. 2003), but omitting testosterone in the culture medium. Indeed, Boitani and co-workers (1993) have shown that, as opposed to $\mathrm{FSH}$, testosterone has no effect on the preservation of the cellular morphology of testicular explants from immature rats. Ovine National Institute of Health FSH-20 was obtained through the National Hormone and Peptide Programme, the National Institute of Diabetes and Digestive and Kidney Diseases, and Dr A F Parlow. Between 20 and 25 animals were used for each culture. Culture was started at day 0 in the absence or presence of $\operatorname{GDNF}(2 \cdot 5,10$, or $50 \mathrm{ng} / \mathrm{ml}$ ) (Linnarsson et al. 2001, Powers et al. 2001). In order to focus on the S-phase of spermatogonial mitosis (not S-phase of meiosis), we limited the time of culture to $48 \mathrm{~h}$ and added $\operatorname{BrdU}(1 \mu \mathrm{M})$ to the culture medium during the last $20 \mathrm{~h}$. On day 2, the cells were detached from the culture dishes by trypsination. Cell viability was assessed by Trypan 
Blue exclusion. Sertoli (vimentin positive) and germ cells (vimentin negative) were sorted by flow cytometry as described below, collected on slides, and BrdU was revealed by immunodetection (see below).

Immunolabeling and flow cytometric analyses

Cultured cells from seminiferous tubules of 7- to 8-day-old rats or cells isolated from freshly prepared seminiferous tubules of 15- or 90-day-old rat testes (ten and four animals respectively) by collagenase and trypsin treatment (Weiss et al. 1997, Godet et al. 2000) were fixed in 70\% ethanol, then immunolabeled with an anti-vimentin antibody followed by an anti-mouse phycoerythrin (PE) conjugated antibody as previously described in details (Godet et al. 2000, 2004).

Cell sorting of cultured Sertoli cells and spermatogonia Hoechst 33342 at a final concentration of $20 \mu \mathrm{g} / \mathrm{ml}$ was added to the immunolabeled cells from cultured tubule
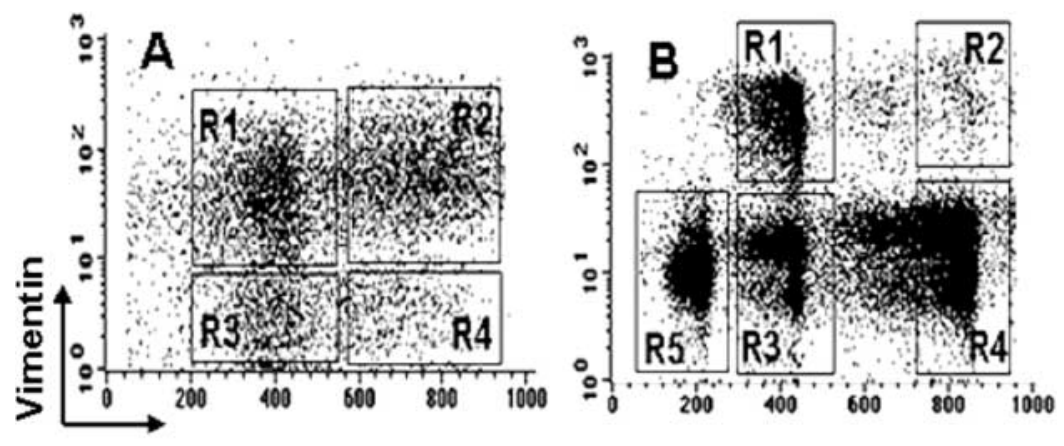

\section{Hoechst}
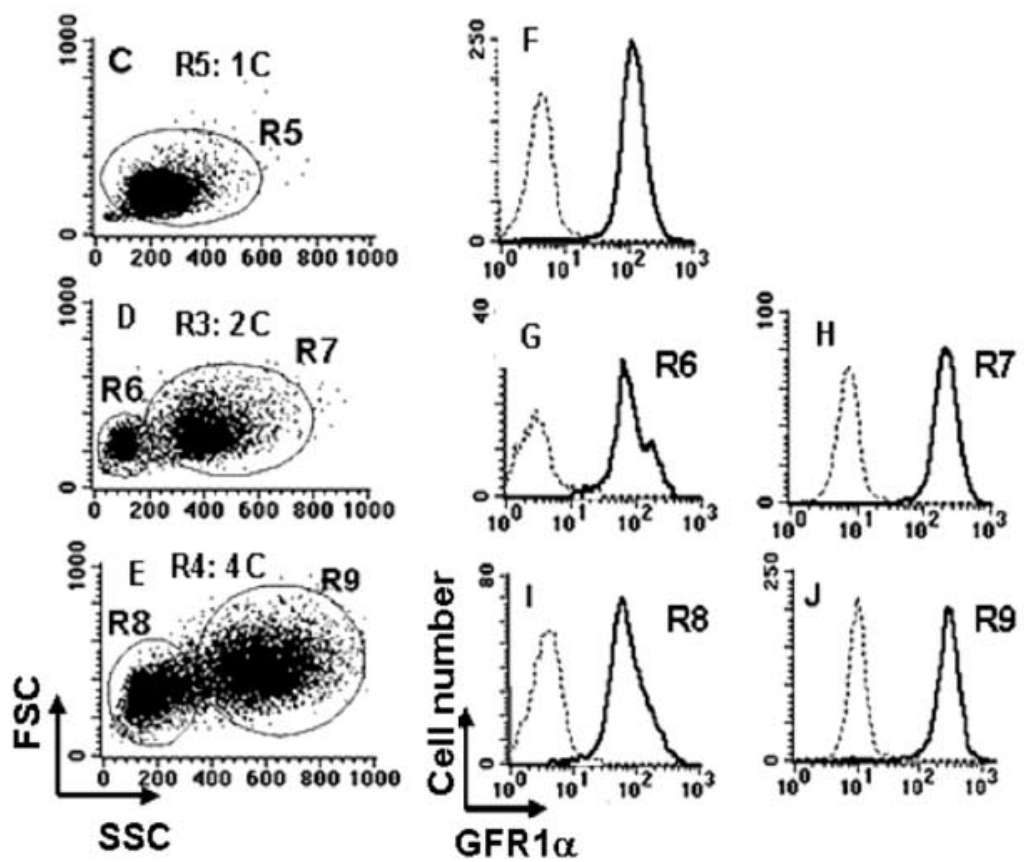

Figure 1 Representative flow cytometry analysis of the cell populations of (A) cultured seminiferous tubule segments of 7-8-day-old rats or of (B-E) seminiferous tubules from pubescent rats and (F-J) GFR1 $\alpha$ labeling of these latter germ cell populations. Distribution of vimentin-positive diploid (R1) and tetraploid (R2) Sertoli cells or vimentin-negative diploid (R3), tetraploid (R4), and haploid (R5) populations of germ cells according to their ploidy (A and B). The different germ cell populations of pubescent rats were subsequently characterized according to their forward light scatter (FSC) and side angle light scatter (SSC) (C-E). Isotype control (---) and GR1 $\alpha$ labeling (-) (F-J) of the different germ cells populations of pubescent rats. R5, round spermatids; R6, spermatogonia and preleptotene spermatocytes; R7, secondary spermatocytes and doublets of round spermatids; R8, young spermatocytes; R9, middle to late spermatocytes. 
segments from 7- to 8-day-old rats to assess their DNA content. The vimentin-positive $4 \mathrm{C}$ and $2 \mathrm{C}$ somatic cells and the vimentin-negative $4 \mathrm{C}$ and $2 \mathrm{C}$ germ cells were separated by bivariate analysis (Fig. 1A): DNA content/vimentin, and sorted on slides (500 cells per spot, five spots per slide) for BrdU detection. Analyses were performed using a fluorescence activated Vantage SE cell sorter (FACS; BD Biosciences) equipped with a $50 \mathrm{~mW}$ argon laser, tuned to $488 \mathrm{~nm}$, and an Innova 300 ion multilined/UV laser tuned to UV. Emission fluorescence was measured with a BP 275/26 filter for PE and BP 424/44 filter for Hoescht. Cell sorting were performed with Clone Cyt Plus software and data acquisition with CellQuest Pro 3 software, both from Beckton-Dickinson Le Pont-de-Claix, France.

\section{Quantification of GDNF and GFR1 $\alpha$ in freshly} isolated Sertoli cells and in germ cells To detect and quantify GDNF and GFR $1 \alpha$ in Sertoli cells, PS, RS, and in germ cell populations, which are difficult to purify (spermatogonia and preleptotene spermatocytes, young spermatocytes, and secondary spermatocytes), cells from seminiferous tubules of 15 - or 90-day-old rats were further incubated overnight at $4{ }^{\circ} \mathrm{C}$ with the specific antibody $(15 \mu \mathrm{g} / \mathrm{ml}$ for anti-GDNF antibody and dilution at 1:100 for anti-GFR $1 \alpha$ antibody), then with a fluoresceine isothiocyanate (FITC)-conjugated secondary antibody (antigoat or anti-mouse for GDNF and GFR $1 \alpha$ respectively). Finally, Hoescht 33342 was added to the immunolabeled cells at a final concentration of $20 \mu \mathrm{g} / \mathrm{ml}$. The reactions allowed the quantification of GDNF in germinal and Sertoli cells and of GFR $1 \alpha$ only in germinal cells, as GFR $1 \alpha$ labeling in Sertoli cells was revealed by both PE- and FITC-conjugated antibodies (both anti-vimentin and anti-GFR $1 \alpha$ antibodies being mouse monoclonal). For each experiment (repeated twice), negative controls were performed with non-immune sera to determine background fluorescence for each cell population. Emission fluorescence was measured with a BP 530/30 filter for FITC, a BP 275/26 filter for PE, and a BP 424/44 filter for Hoechst 33342. Results were expressed relative to the FITC fluorescence levels observed in middle/late PS, which were given an arbitrary value of 100 . Analyses were performed as described previously (Godet et al. 2000, 2004). Five data parameters were acquired; linear forward light scatter (FSC) and linear side angle light scatter (SSC), which roughly represent cell size and cellular granularity respectively, logarithmic PE and FITC to detect immunolabeling, and linear Hoescht to measure the DNA content of the different populations of cells. The vimentinnegative germ cells and vimentin-positive somatic cells were separated by bivariate analysis, DNA content/vimentin. For germ cells, three populations with $4 \mathrm{C}, 2 \mathrm{C}$, and $1 \mathrm{C}$ DNA content were selected; the bivariate FSC/SSC analysis identified five populations as described by Godet et al. (2000, 2004) (Fig. 1B-J). Contaminating events such as debris and clumped cells were eliminated from the analysis. Each acquisition was performed on 50000 events.

\section{Immunocytochemistry of BrdU on sorted cells and counting}

For BrdU detection, the cells were first treated with $0 \cdot 03 \%$ Triton X-100, then with 3\% hydrogen peroxide and with $0.07 \mathrm{M} \mathrm{NaOH}$ in $50 \%$ ethanol for $5 \mathrm{~min}$ (DNA denaturation). Incubation was then performed with an anti-BrdU antibody diluted at 1:100 for one night at $4{ }^{\circ} \mathrm{C}$. The staining reaction was performed using 3-amino-9ethylcarbazole or DAB. Cells were counterstained with hematoxylin. BrdU-positive and BrdU-negative cells were counted under microscopic examination.

\section{Electrophoresis and Western blotting}

Proteins were extracted by homogenizing tissues (two pools of testes, at least three animals per age) in $50 \mathrm{mM}$ Tris- $\mathrm{HCl}$ $(\mathrm{pH} 7 \cdot 4), 0 \cdot 5 \mathrm{mM}$ EDTA and $2 \% \mathrm{v} / \mathrm{v}$ of a protease inhibitor cocktail. Elutriated PS and RS and Sertoli cell fractions were lysed by sonication in $50 \mathrm{mM}$ Tris- $\mathrm{HCl}(\mathrm{pH} 7 \cdot 5), 150 \mathrm{mM}$ $\mathrm{NaCl}, 1 \%$ Nonidet P-40, $1 \mathrm{mM} \mathrm{Na} \mathrm{VO}_{4}, 10 \mathrm{mM} \mathrm{NaF}$, $10 \mathrm{mM} \beta$-glycerophosphate, $2 \mathrm{mM}$ EDTA and $2 \% \mathrm{v} / \mathrm{v}$ of a protease inhibitor cocktail. Protein concentrations were determined with BCA kit from Pierce. SDS-PAGE separation was carried out according to the method of Laemmli (1970) on polyacrylamide gels (9\% for RET detection, $12 \%$ for other immunodetections). One hundred and fifty micrograms protein per well were loaded for RET and $50 \mu \mathrm{g}$ for other determinations. After electrotransfer, nitrocellulose membranes were stained with Ponceau Red S to verify that the same amount of protein was loaded for each well. Reactions were carried out in $1 \times$ PBS $-0 \cdot 05 \%$ Tween. The membranes were incubated with the specific antibodies diluted as follows: anti-vimentin antibody 1:3000; anti-GFR $1 \alpha$ antibody 1:5000; anti-RET antibody 1:2500; anti-GDNF antibody was diluted to $0.1 \mu \mathrm{g} / \mathrm{ml}$. After incubation with appropriate secondary HRP-conjugated antibodies, detection was performed by chemiluminescence (ECL Plus Western Blotting Detection System; Amersham).

\section{Detection of GFR $1 \alpha$ and GDNF by fluorescence confocal microscopy in isolated testicular cells}

Freshly prepared germ cell and Sertoli cell fractions (Weiss et al. 1997, Godet et al. 2004) were immunolabeled as for flow cytometry analysis except (1) for vimentin revelation, the LSAB kit (DakoCytomation SA) and DAB or a FITCconjugated secondary antibody were used; (2) GDNF and GFR $1 \alpha$ were revealed by PE- or cyanin 3-conjugated secondary antibodies. Cells were mounted in Gel/Mount (Biomeda Corp., Foster City, CA, USA). Scanning fluorescence images were acquired using a confocal laser unit 
(Leica $\mathrm{TCSSP}_{2}$ ) coupled to a microscope equipped with a $\times 63$ oil immersion objective. In control reactions, the first antiserum was replaced by normal (non-immune) $\operatorname{IgG}$ used at the same concentration as the first antiserum.

\section{$m R N A$ extraction and $R T-P C R$}

Total RNA was prepared from frozen tissues (testes and pituitary) or cell pellets using Trizol reagent. RT was performed on at least two different pools of testes or cell pellets by M-MLV RT following the manufacturer's instructions. PCR (denaturation $94^{\circ} \mathrm{C}$, annealing $62{ }^{\circ} \mathrm{C}$, elongation $72{ }^{\circ} \mathrm{C}, 30$ cycles) was performed in an Eppendorf thermocycler using the pairs of forward $(\mathrm{F})$ and reverse $(\mathrm{R})$ primers previously used by Urbano et al. (2000) to detect GDNF, GFR $1 \alpha$, and RET cDNA in anterior pituitary gland tissue (used as a positive control in our experiments): GDNF: (F): 5' ATG AAG TTA TGG GAT GTC GTG GCT 3' (exon 1); (R): $5^{\prime}$ GGG TCA GAT ACA TCC ACA CCG (exon 2). GFR1 $\alpha$ : (F): $5^{\prime}$ GCA CAG CTA CGG GAT GCT CTT CTG $3^{\prime}$; (R): $5^{\prime}$ GTA GTT GGG AGT CAT GAC TGT GCC AAT C $3^{\prime}$. RET: (F): $5^{\prime}$ CGG CAC ACC TCT GCT CTA TG $3^{\prime}$ (exon 2); (R): $5^{\prime}$ CTG GAG GAA GAC GGT GAG CA $3^{\prime}$ (exon 3).

These pairs of primers produced specific bands of 640, 286, and $235 \mathrm{bp}$ for GDNF cDNA, GFR $1 \alpha$, and RET respectively. The cDNAs were ligated in pGEM-T vector and plasmids were amplified (Qiagen Midi kit) and sequenced (Biofidal, Vaulx-en-Velin, France).

\section{Statistical analysis}

ANOVA was used to compare data from more than two groups. Paired $t$-test was used to assess statistical differences between treated cells and their corresponding control cells.

\section{Results}

GDNF, GFR $1 \alpha$, and RET proteins and $m R N A$ s during postnatal development of the rat testis

The specificity of the commercial anti-GDNF and antiGFR $1 \alpha$ antibodies was tested by Western blotting: only specific bands at the expected size were observed and no nonspecific bands (see below and data not shown).

GDNF protein and mRNA (Fig. $2 \mathrm{~A}-\mathrm{C}$ ), GFR $1 \alpha$ protein and mRNA (Fig. 2D and E) and RET mRNA (Fig. 2F) were detected in the rat testis from 1 to 90 days postnatally. The GDNF protein had an apparent molecular weight (MW) of $15 \mathrm{kDa}$ under reducing conditions (Fig. 2A and B) and of $30 \mathrm{kDa}$ under non-reducing conditions (Fig. 2B) as in the rat brain (Lin et al. 1993). The GFR $1 \alpha$ protein migrated as a doublet with a MW of 55-60 kDa (Fig. 2D). The RET protein was not detected in total testicular protein extracts (not shown). The mRNAs corresponding to these proteins were detected at the expected sizes: 640, 286, and $235 \mathrm{bp}$ for
GDNF (Fig. 2C), GFR1 $\alpha$ (Fig. 2E), and RET (Fig. 2F) respectively at all ages.

Cellular localization of GDNF and GFR $1 \alpha$ proteins and $m R N A$, and RET $m R N A$ in the rat testis

Localization of GDNF and GFR1 $\alpha$ proteins and mRNA, and RET mRNA in purified fractions of germinal and Sertoli cells PS and RS fractions recovered by elutriation from adult rat testes were free from detectable somatic cell contamination, as shown by the absence of a vimentin signal (Fig. 3A). GDNF (Fig. 3B and C), GFR $1 \alpha$ (Fig. 3D and E) proteins and mRNAs, and RET mRNA (Fig. 3F) were detected in PS (from 22- and 90-day-old rats), and RS (from 90-day-old rats), and in Sertoli cells (from 20 - and 55-day-old rats). The GFR $1 \alpha$ protein appeared as a single band with a MW of $55 \mathrm{kDa}$ in PS and SR, whereas two bands with a MW of 55-60 kDa were present in Sertoli cells (Fig. 3D).

\begin{abstract}
Localization and relative amounts of GDNF and GFR1 $\alpha$ proteins in germinal and Sertoli cells assessed by flow cytometry GDNF (Fig. 4A) and GFR $1 \alpha$ (Fig. 4B) proteins were detected in the five germ cell populations obtained by flow cytometry in the adult rat (see Fig. 1): (1) spermatogonia and preleptotene spermatocytes, (2) young spermatocytes, (3) middle to late PS, (4) secondary spermatocytes and doublets of RS, and (5) round and elongating spermatids. Likewise, at the age of 15 days, both proteins were detected in the populations corresponding to spermatogonia + preleptotene spermatocytes and young spermatocytes, the only germ cells present at this age. GDNF was also detected in Sertoli cells at both ages.
\end{abstract}

Localization of GDNF and GFR1 $\alpha$ in germinal and Sertoli cells by immunocytochemistry and scanning fluorescence microscopy As a confirmation of the results presented above, the immunoreactivity of GFR1 $\alpha$ (Fig. 5) and GDNF (Fig. 6) was observed in both Sertoli and germ cells (spermatogonia, PS, and RS). As expected, the labeling of GFR $1 \alpha$ was localized at the cell periphery, while that of GDNF appeared within the cells.

In vitro effect of GDNF on DNA synthesis (labeling index) of Sertoli cells and type A spermatogonia in the immature rat

Seminiferous tubules from 7- to 8-day-old rats were cultured for 2 days in the absence or presence of different concentrations of GDNF, and the numbers of somatic and germ cells in S-phase were determined by BrdU labeling after cell sorting (see Fig. 1A). Cell viability was close to 95\% throughout the culture period, irrespective of the absence $(5 \cdot 1 \pm 0 \cdot 6 \%$ of dead cells) or presence $(4 \cdot 9 \pm 0 \cdot 6 \%$ of dead 
GDNF

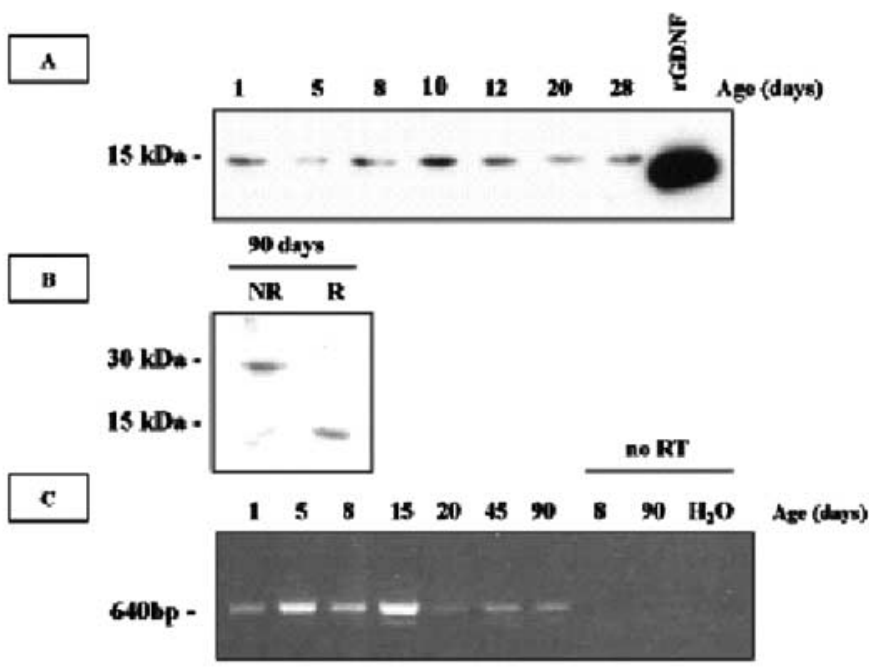

GFR1a

RET
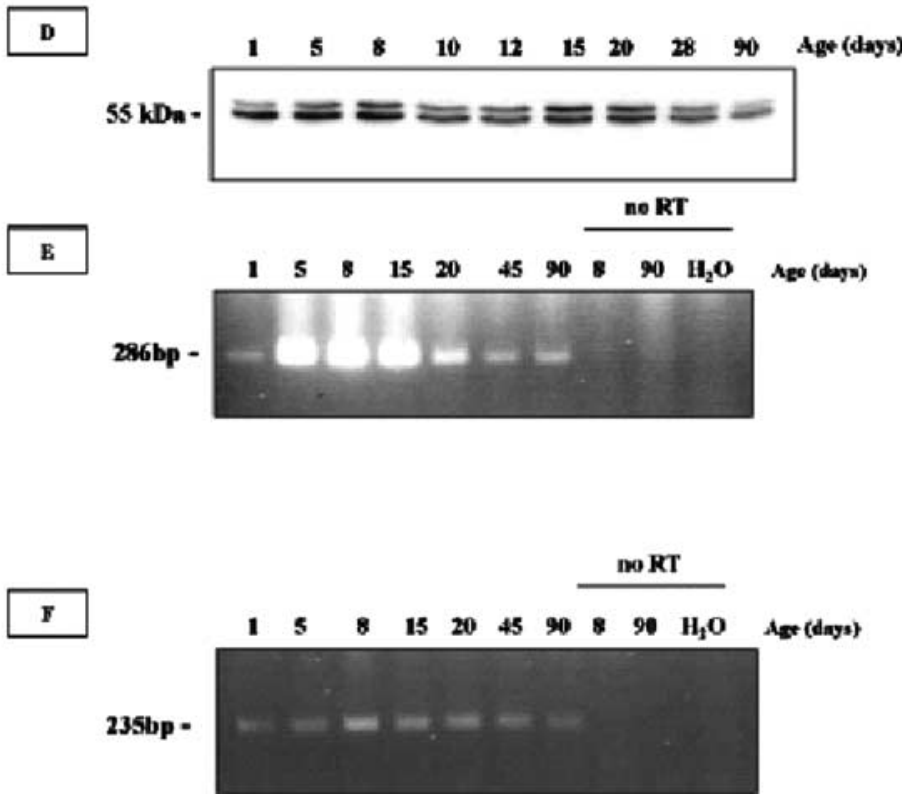

Figure 2 Detection of GDNF, GFR1 $\alpha$, and RET mRNA and proteins during postnatal development of the rat testis. GDNF (A and B) and GFR1 $\alpha$ (D) proteins were

immunodetected in total testicular protein extracts at the ages of 1, 5, 8, 10, 12, 20, 28 , and 90 days by Western blotting. For GDNF, recombinant GDNF was used as a positive control (A) and migration was performed under reducing (R) conditions for samples corresponding to ages from 1 to 28 (A) and 90 days (B) and under nonreducing (NR) conditions for the latter sample (B). For GFR1 $\alpha(D)$, migration was performed under reducing conditions. The molecular weights are indicated on the left. mRNAs coding for GDNF (C), GFR1 $\alpha(E)$ and RET (F) were detected by RT-PCR using total RNA from rat testes at the ages of 1, 5, 8, 15, 20, 45, and 90 days. Negative controls (no reverse transcriptase, no RT) were performed with RNA from testes at the ages of 8 and 90 days, and without sample $\left(\mathrm{H}_{2} \mathrm{O}\right)$. cDNA length is indicated on the left in bp. At least two RNA preparations and three protein preparations were tested with similar results. 
Vimentin

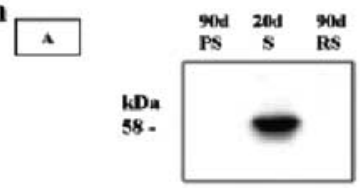

\section{GDNF}

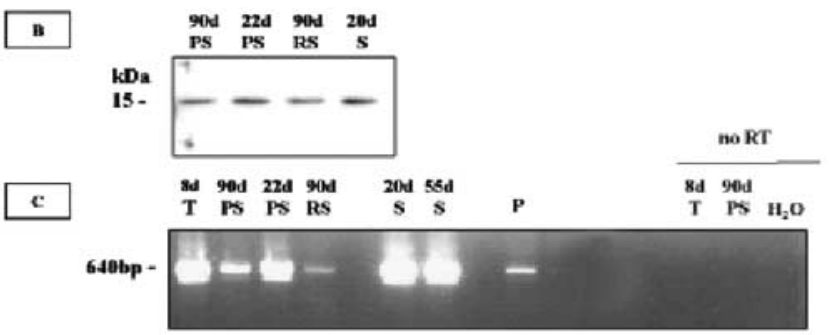

GFR1 $\alpha$

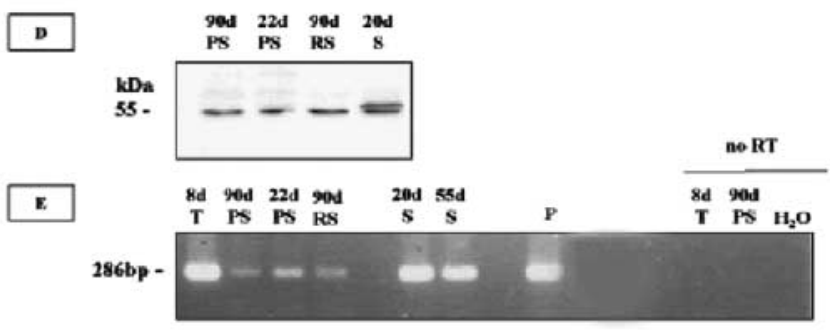

RET

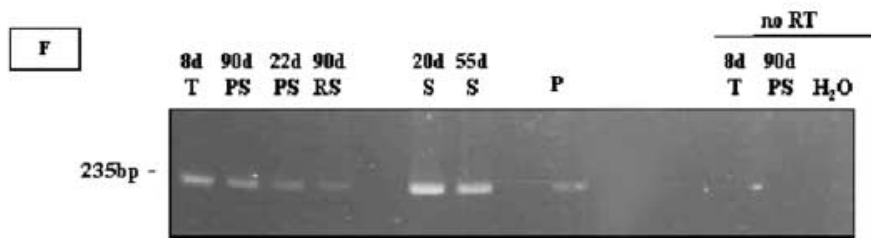

Figure 3 Cellular localization of vimentin, GDNF, GFR $1 \alpha$, and RET in the rat testis. The presence of the proteins vimentin (A), GDNF (B), and GFR1 $\alpha$ (D) was investigated by Western blotting in the following fractions: pachytene spermatocytes (PS) and round spermatids from 90-day (d)-old rats (90d PS and 90d RS respectively) and Sertoli cells from 20-day-old rats (20d S). The presence of GDNF and GFR1 $\alpha$ proteins was also investigated in PS from 22-day-old rats (22d PS) (B and D). The molecular weights are indicated on the left. mRNAs coding for GDNF (C), GFR1 $\alpha$ (E) and RET (F) were detected by RT-PCR using total RNA from testicular tissue from 8-day (d)-old rats (8d T); PS from 22- and 90-day-old rats (90d PS and 22d PS); round spermatids obtained from 90-day-old rats (90d RS); and Sertoli cells from 20- and 55-day-old rats (20d S and 55d S). Pituitary gland (P) was also tested. Negative controls (no RT) were performed with RNA from 8-day (8d T)-old rat testes, adult PS (90d PS), and without sample $\left(\mathrm{H}_{2} \mathrm{O}\right)$. cDNA length is indicated on the left in bp. At least two RNA preparations and three protein preparations were tested with similar results.

cells) of GDNF. The proportion of somatic cells in S-phase was not changed in the presence of GDNF (Fig. 7A). By contrast, GDNF induced a significant decrease in the proportion of BrdU-labeled spermatogonia (Fig. 7B) when used at $10 \mathrm{ng} / \mathrm{ml}(0 \cdot 19 \pm 0 \cdot 04$ versus $0 \cdot 34 \pm 0 \cdot 08)$, or $50 \mathrm{ng} /$ $\mathrm{ml}(0 \cdot 22 \pm 0 \cdot 08)$, both $P<0 \cdot 01$, but not at $2 \cdot 5 \mathrm{ng} / \mathrm{ml}$. Similar results were observed after 5 days of culture for both somatic and germ cells (data not shown).

\section{Discussion}

Expression and localization of GDNF and its receptors in the rat testis during postnatal development

This is the first time, to our knowledge, that the localization of GDNF and its receptors, GFR $1 \alpha$ and RET, has been investigated in different cell types of the rat testis in the same 

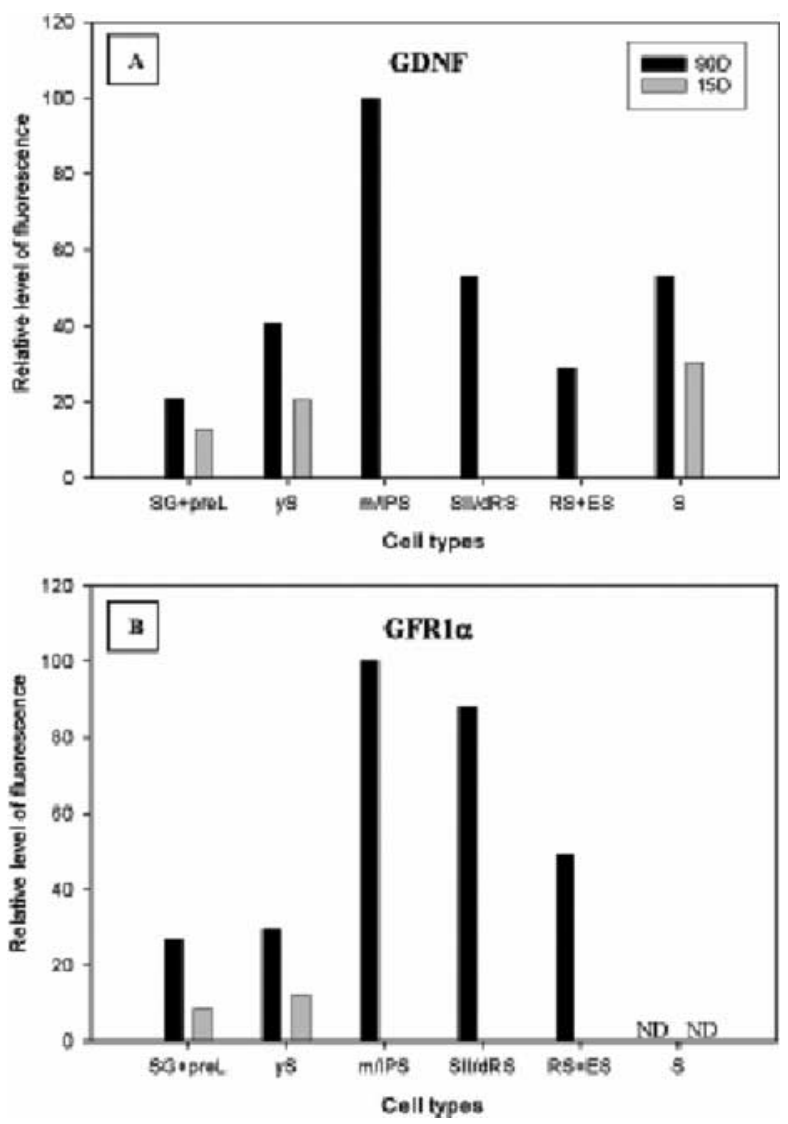

Figure 4 Determination of relative GDNF and GFR1 $\alpha$ levels in germ and Sertoli cells separated by flow cytometry. Relative GDNF (A) and GFR1 $\alpha$ (B) levels in germ cells, and relative GDNF levels in Sertoli cells were determined from 15- (gray) and 90- (black) day-old rats. Five germ cell populations were obtained from 90-dayold rat testes: (1) spermatogonia (SG) and preleptone spermatocytes (preL), (2) young spermatocytes (yS), (3) middle to late PS (m-I PS), (4) secondary spermatocytes (SII) and doublets of round spermatids $(\mathrm{dRS})$, and (5) round (RS) and elongating spermatids (ES). At the age of 15 days, the only germ cells present were SG+ preL and yS. The level of GFR1 $\alpha$ was not determined in Sertoli cells $(S)$ as both anti-vimentin and anti-GFR $1 \alpha$ were monoclonal antibodies. Results shown are the mean of two independent experiments and are expressed relative to the level of fluorescence observed in $\mathrm{m}-\mathrm{I}$ PS, which were given an arbitrary value of 100 .

study throughout postnatal development. Most of our findings were obtained at the protein level by several techniques and were confirmed at the mRNA level. GDNF and GFR $1 \alpha$ proteins and mRNA and RET mRNA were observed from 1 to 90 days of age, and were present in Sertoli cells, PS, and RS. GDNF and GFR $1 \alpha$ proteins were also detected in spermatogonia and preleptotene spermatocytes and in secondary spermatocytes.

In the mouse, GDNF mRNA and protein were first localized only in Sertoli cells (Meng et al. 2000, Viglietto et al. 2000). However, more recently, GDNF mRNA was reported in gene expression profiles of germ cells from spermatogonia to spermatids (Yu et al. 2003). In the human testis, GDNF protein is present in both somatic (Sertoli and Leydig) and germ (spermatocytes, RS) cells (Davidoff et al. 2001). In the mouse, GFR $1 \alpha$ was shown to be restricted to a subset of spermatogonia (Meng et al. 2001, Dettin et al. 2003, Buageaw et al. 2005, Hofmann et al. 2005), whereas RET was detected in more differentiated germ cells (up to spermatids) (Cao et al. 1996, Creemers et al. 2002). By contrast, in human, GFR $1 \alpha$ immunoreactivity was reported in Sertoli and Leydig cells, but not in germ cells (Davidoff et al. 2001). It might be argued that the cell fractions used in our studies are not $100 \%$ pure. However, such an explanation cannot hold for all the differences observed between the mouse and the rat. (1) It is inconceivable that the presence of the protein GFR $1 \alpha$ in PS, RS, or Sertoli cells could be explained by a contamination of these fractions by a sufficient number of GFR $1 \alpha$ expressing spermatogonial stem cells which are in very low number in the testis (Orwig et al. 2002, Dettin et al. 2003, Ryu et al. 2003, 2005, Buageaw et al. 2005, Hofmann et al. 2005). (2) The molecular forms of GFR $1 \alpha$ are not identical in Sertoli and germ cells (see below). (3) The contamination of the germ cell fractions by Sertoli cells was below the threshold of detection of the intermediate filament vimentin. (4) The results obtained with the methods used to detect GDNF and GFR $1 \alpha$ at a one cell level (FACS analysis and immunocytochemistry) corroborated quite well with the biochemical approaches. Taken together, these results might indicate species variability in the localization of the GDNF pathway in the testis.

It might be objected that it is not logical to evaluate Sertoli cells from 20-day-old rats and germ cells from 90-day-old rats. However, the results obtained with the Sertoli cells from 55-day-old rats (an age by which all the germ cell populations, including postmeiotic germ cells, are present in the testis) were quite similar to those obtained with Sertoli cells from younger animals (see Fig. 3). Moreover, for those proteins and cell populations that could be studied by cytometry, the results were close at 15 and 90 days (see Fig. 4).

Aside from the localization of the GDNF pathway in the rat testis, two points deserve further discussion. First, GFR $1 \alpha$, which is a protein of 468 amino acids with an N-terminal hydrophobic domain characteristic of a secretory signal peptide, was detected in testis extracts as a doublet (MW $55-60 \mathrm{kDa}$ ) as in the rat brain and pituitary, where the upper band was suspected of being related to the precursor and the lower band to the mature form (without the signal peptide) (Matsuo et al. 2000). Surprisingly, the upper band (MW $60 \mathrm{kDa}$ ) was present in Sertoli cells but not in germ cells, which exhibited only the lower band (MW $55 \mathrm{kDa}$ ). The significance of the presence of the precursor in Sertoli cells is unknown and needs further investigation. Secondly, it should be emphasized that the Western and the Northern blotting methods, as used in the present study to detect GDNF, GFR $1 \alpha$ or RET proteins or mRNAs, are in no sense quantitative methods. Hence, no conclusion about the relative levels of either protein or mRNA between the different samples can be made. This also holds true for 

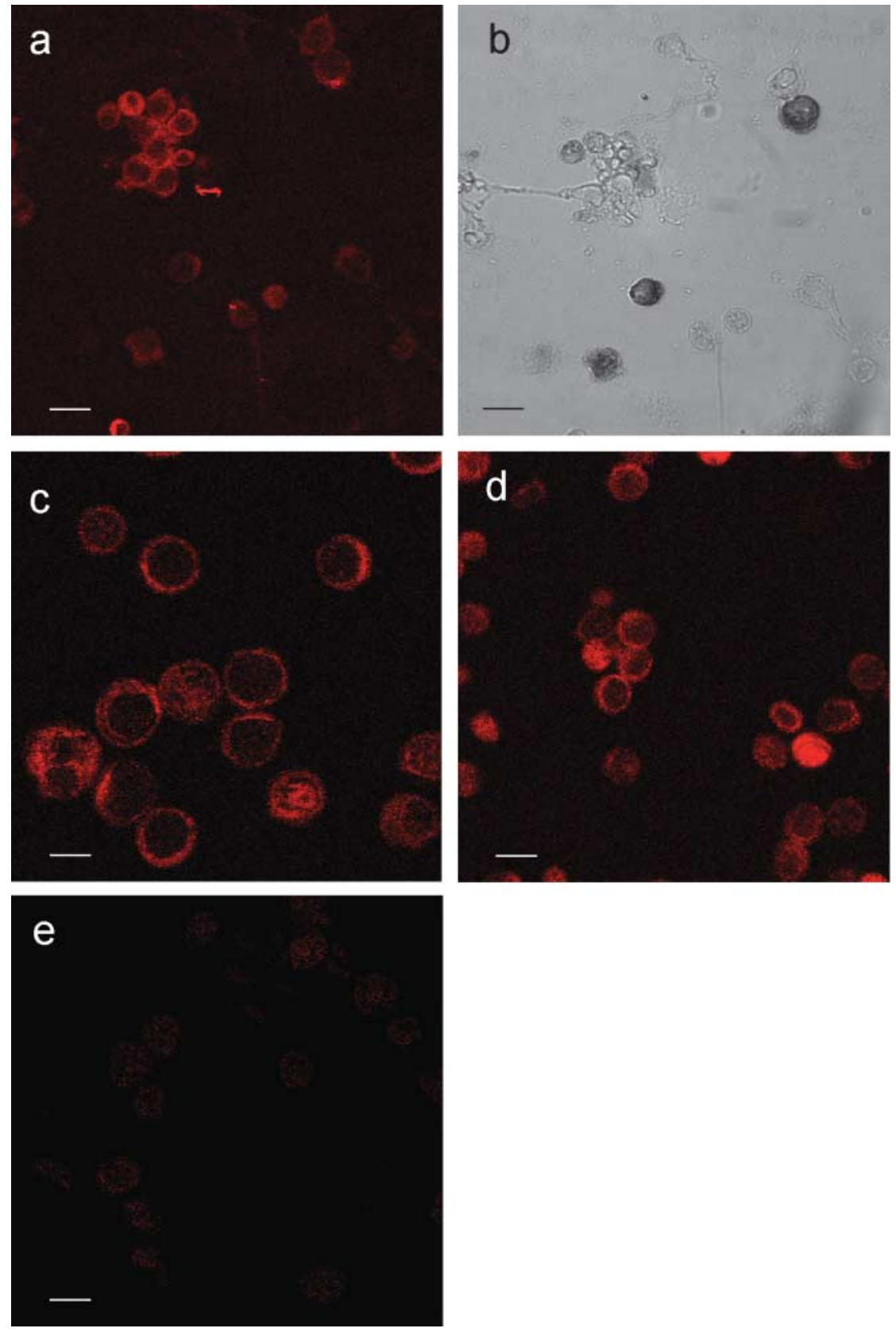

Figure 5 Scanning immunofluorescence immunocytochemical localization of GFR1 $\alpha$ in freshly prepared spermatogonia, PS, RS, and Sertoli cells. GFR1 $\alpha$ was detected in (a) spermatogonia (vimentin negative) and Sertoli cells (vimentin positive). (b) Transmission microscopy of (a) shows the vimentin labeling of the Sertoli cells (revealed with DAB). (c) PS, (d) RS, and (e) corresponding control (reaction with control mouse IgG for RS). All bars $=10 \mu \mathrm{m}$.

a comparison between the relative levels observed by FACS analysis (on a per cell basis) and those obtained by Western or Northern blots (on a protein- or RNA-amount basis). Taken together, the above results support the view that GDNF, GFR $1 \alpha$, and RET exhibit overlapping patterns of expression in the rat testis and are constitutively expressed. Such an overlapping pattern for GDNF and its receptors has been found in other tissues such as the retina, where GDNF can stimulate fiber growth from ganglion cells (Karlsson et al. 2002). This suggests that GDNF participates in auto and/or 

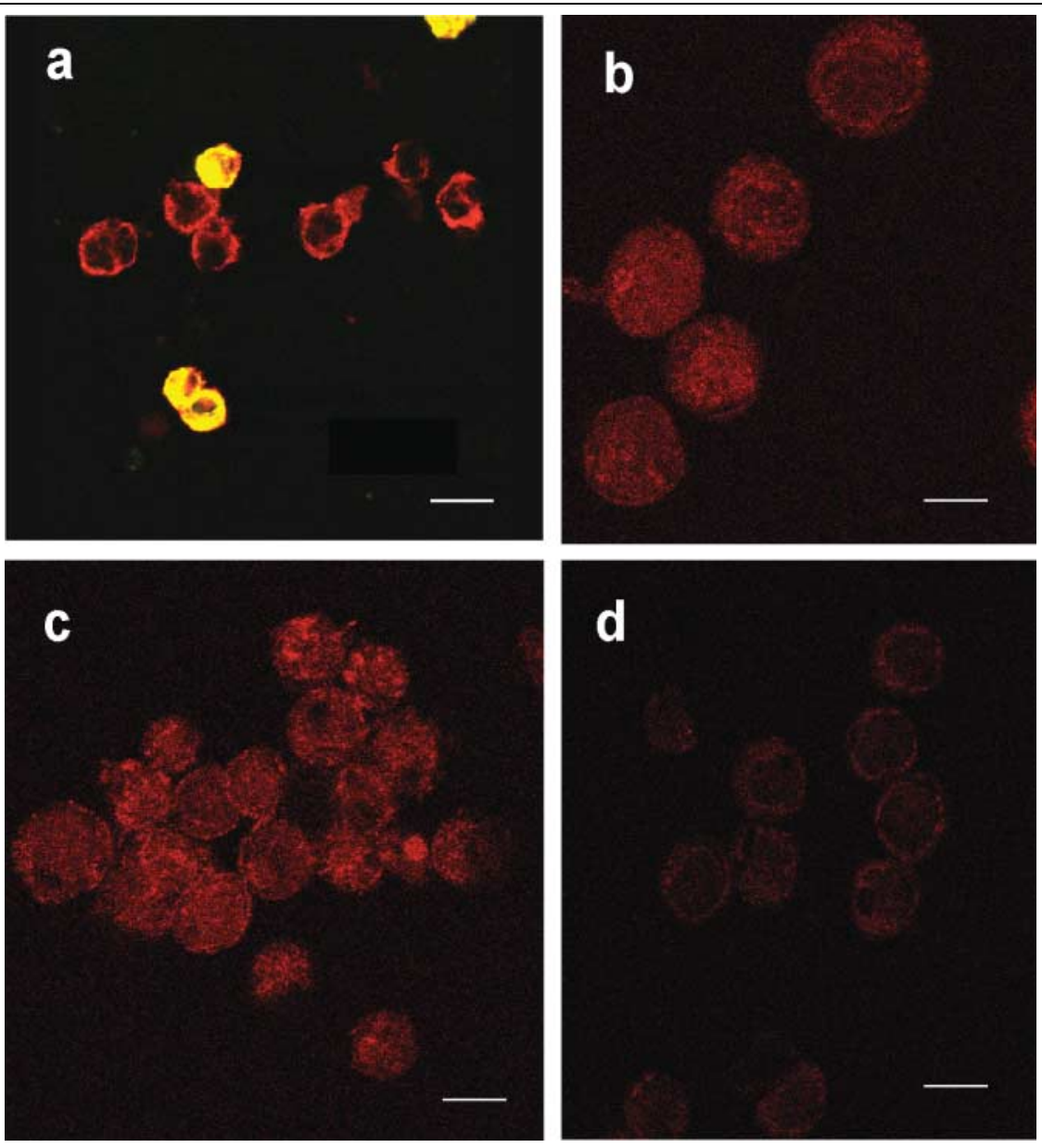

Figure 6 Scanning fluorescence immunocytochemical localization of GDNF in freshly prepared spermatogonia, PS, RS, and Sertoli cells. GDNF was detected in (a) spermatogonia (vimentin negative) and Sertoli cells (vimentin positive). Note that vimentin was revealed with a FITC conjugated secondary antibody giving a yellow staining when both GDNF (red) and vimentin (green) are expressed in the same cells. (b) PS, (c) RS, (d) corresponding control (reaction with control goat lgG for PS). All bars $=10 \mu \mathrm{m}$.

paracrine cellular mechanisms in the testis and may influence both somatic and germ cell functions throughout postnatal development.

\section{Biological effect of GDNF in seminiferous tubules in vitro}

In different organs, GDNF may have either stimulatory or inhibitory effects on DNA synthesis and cell proliferation in vitro through $\mathrm{RET} / \mathrm{GFR} 1 \alpha$ signaling. For example, it stimulates the proliferation of enteric neurons and glial progenitors (Heuckeroth et al. 1988), but inhibits the proliferation of the embryonic carcinoma cell line NT2/D1 (Baldassarre et al. 2002). Human adrenal chromaffin cells respond to GDNF by differentiation (Powers et al. 1998) or mitogenesis (Powers et al. 2001) according to their in vitro environment.

In the rat testis, Sertoli cells stop proliferating around 15 days of age (Steinberger \& Steinberger 1971, 1977). In our study, using 7- to 8-day-old rat seminiferous tubule cultures, the labeling index of Sertoli cells was around $4 \%$, similar to the indices reported previously in 3-day cultures of 6-and 9-day-old rats (Boitani et al. 1993, 1995, Schlatt et al. 1999). We found that GDNF did not affect the percentage of Sertoli cells duplicating their DNA, in contrast to what $\mathrm{Hu}$ et al. reported in testicular explants of younger rats (6 days old) (1999). This apparent divergence may be related to different experimental conditions or more likely to the different age of the animals. Indeed, the same authors have shown that FSH increases the labeling index of Sertoli cells at the age of 6 days, whereas two previous studies have shown that this index is FSH-independent at the age of 9 days in a similar culture system (Boitani et al. 1995, Schlatt et al. 1999). Thus, the positive effect of GDNF on the Sertoli cell labeling index observed by Hu et al. (1999) may be limited to a very defined period of development. Hence, our results do not suggest a significant action of GDNF on the regulation of Sertoli 

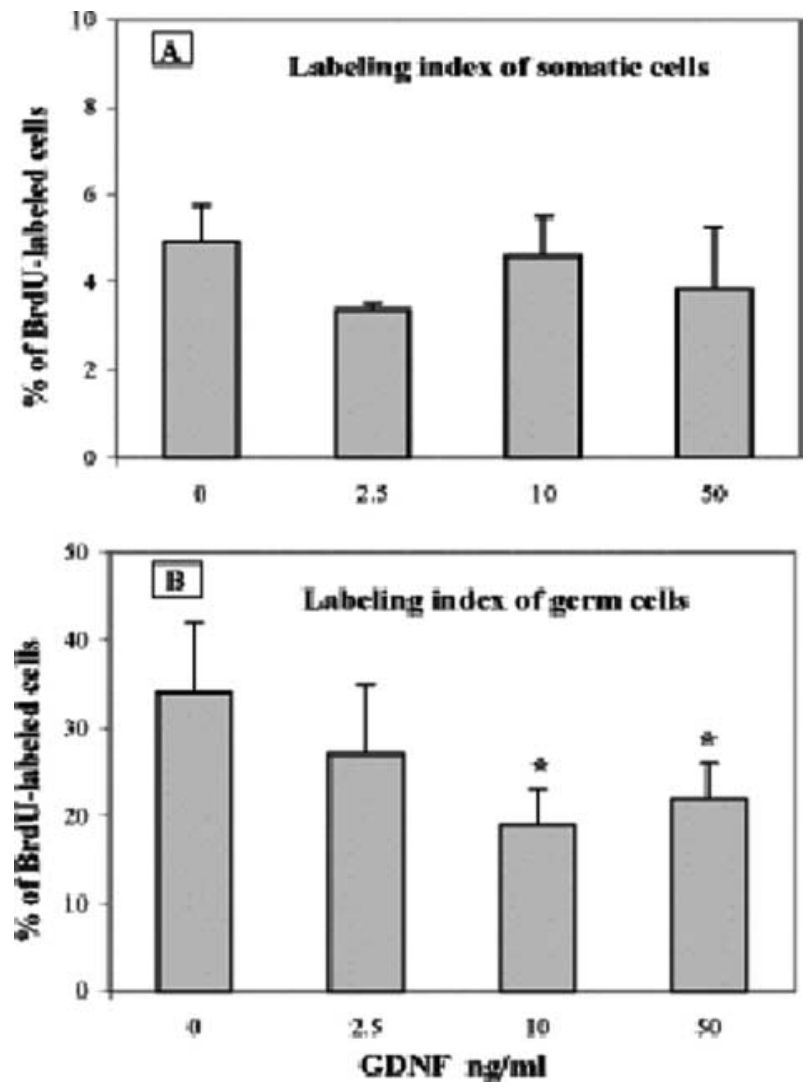

Figure 7 Effect of GDNF on DNA synthesis of Sertoli cells (A) and spermatogonia (B). Seminiferous tubule segments from 7- to 8-dayold rats were cultured for 2 days in the absence or presence $(2 \cdot 5$, 10 , and $50 \mathrm{ng} / \mathrm{ml}$ ) of GDNF. One micromole BrdU was added to the medium for the last $20 \mathrm{~h}$ of culture. The proportion of BrdU-labeled Sertoli cells (2C vimentin-positive cells) and spermatogonia (2C vimentin-negative cells) was determined by immunodetection on slides, after cells were sorted by flow cytometry. Values are the means \pm s.E.M. of five independent experiments for 2.5 and $10 \mathrm{ng} / \mathrm{ml}$, and three for $50 \mathrm{ng} / \mathrm{ml} .{ }^{*} P<0 \cdot 01$ versus control $(0)$.

cell mitosis in 7- to 8-day-old rats. Besides, the number of Sertoli cells is not affected in GDNF overexpressing mouse testes (Meng et al. 2000).

In control wells, the labeling index of spermatogonia found in our study was very close (around 35\%) to that reported by Boitani et al. using similar conditions (age of rats and culture medium) (Boitani et al. 1993, 1995). The proportion of BrdU-labeled spermatogonia was reduced by GDNF by around twofold. In 7- to 8-day-old rat testes, only type A spermatogonia are present (Boitani et al. 1993, Dym et al. 1995, Jahnukainen et al. 2004). Hence, these results suggest that GDNF inhibits the S-phase entrance of a large subset of type A spermatogonia under our culture conditions.

In the mouse, and more recently in the rat, the in vitro studies reported in the literature have shown a positive effect of GDNF on the number of spermatogonial stem cells which are a small subset of type A spermatogonia (Kamatsu- Shinohara et al. 2003, Nagano et al. 2003, Kubota et al. 2004a, 2004b,
Hofmann et al. 2005, Ryu et al. 2005). It has been proposed that this effect is due to self-renewing of stem cells encouraged by suppression of the differentiation pathway (Nagano et al. 2003). This hypothesis fits quite well with the results of the in vivo studies. Although fertile, knockout mice with one GDNF-null allele show a depletion of undifferentiated spermatogonia (Meng et al. 2000). Moreover, undifferentiated spermatogonia self-renew in mice overexpressing GDNF in the testis, but do not differentiate (Meng et al. 2000, Creemers et al. 2002, Yomogida et al. 2003). Likewise, in heterozygous mutants for the dominant white spotting locus and steel locus encoding the c-kit receptor and the c-kit ligand (stem-cell factor) respectively high levels of GDNF are observed in the testis, in which undifferentiated spermatogonia actively proliferate, but are decreased in number and do not differentiate (Tadokoro et al. 2002). In an extensive study, quantifying type A spermatogonia in the adult rat seminiferous epithelium, Huckins (1971) calculated the proportion of undifferentiated type Ais and Apr spermatogonia (stem cells) to be $11 \%$ of total type A spermatogonia. Moreover, Orwig et al. (2002) and Ryu et al. (2003) demonstrated only moderate differences in stem-cell concentration between adult and neonate rat testes. Taken together, these results indicate that the population of type A spermatogonia studied in our work was most likely composed of at least $80 \%$ of differentiated type A spermatogonia. Hence, it seems reasonable to suggest that the overall effect of GDNF observed in the present study is the sum of an inhibitory effect of GDNF on the large population of differentiated spermatogonia together with an enhancing effect of the factor on a small population of undifferentiated (stem cells) spermatogonia. This assumption appears substantiated by the results showing that even at maximal concentration, GDNF did not induce a decrease of the labeling index of spermatogonia higher than 50\% (see Fig. 7).

Presently, the effects and means of action of GDNF on spermatogonia remain not completely understood in all studied species. For instance, the number of bovine spermatogonial stem cells arising from cells cultured with GDNF was lower than in controls after 1 week of culture, but higher than controls after 2 weeks (Oatley et al. 2004). Although some mouse spermatogonial stem cells can survive for more than 3 months in culture (Nagano et al. 1998), about 50 and $90 \%$ are lost after 3 and 7 days of culture respectively (Nagano et al. 2001). Spermatogonial stem cells derived from DBA/2J strain mice can be cultured in serum-free medium supplemented with GDNF alone, whereas spermatogonia from other strains cannot, suggesting an inherent genetic difference between strains (Kubota et al. 2004b). Besides, Buageaw et al. (2005) have shown that the stem-cell pool of immature mouse testes is heterogeneous with respect to the level of GFR $1 \alpha$ expression.

In conclusion, our in vitro results indicate that GDNF inhibits the S-phase entrance of differentiating A spermatogonia. Finally, the wide temporal and spatial expression of GDNF and its two receptors in the rat testis suggest that GDNF might act at several stages of spermatogenesis by either a direct effect on 
the different types of germ cells and/or by an indirect action through Sertoli cells. Further investigations using similar in vitro approaches are in progress to answer these questions.

\section{Acknowledgements}

The authors are very grateful to Dr Serge Manié for the gift of the anti-RET antibody, to M Vigier for excellent technical help for elutriation techniques, and to Drs M H Perrard and E Delolme for assistance in cytology. Confocal microscopy was performed at the Centre Commun de Quantimétrie, Université Claude-Bernard Lyon 1. J Bois and M A Di Carlo are acknowledged for excellent secretarial assistance.

\section{Funding}

This work was supported by Institut National de la Santé et de la Recherche Médicale, Institut National de la Recherche Agronomique and Université Claude Bernard Lyon 1. The authors declare that there is no conflict of interest that would prejudice the impartiality of the research reported.

\section{References}

Baldassarre G, Bruni P, Boccia A, Salvatore G, Melillo RM, Motti ML, Napolitano M, Belletti B, Fusco A, Santoro M et al. 2002 Glial cell line-derived neurotropic factor induces proliferative inhibition of NT2/D1 cells through RET-mediated up-regulation of the cyclin-dependent kinase inhibitor p27(kip1). Oncogene 21 1739-1749.

Boitani C, Politi MG \& Menna T 1993 Spermatogonial cell proliferation in organ culture of immature rat testis. Biology of Reproduction $\mathbf{4 8}$ 761-767.

Boitani C, Stefanini M, Fragale A \& Morena AR 1995 Activin stimulates Sertoli cell proliferation in a defined period of rat testis development. Endocrinology 136 5438-5444.

Buageaw A, Sukhwani M, Ben-Yehudah A, Ehmcke J, Rawe VY, Pholpramool C, Orwig KE \& Schlatt S 2005 GDNF family receptor alpha1 phenotype of spermatogonial stem cells in immature mouse testes. Biology of Reproduction 73 1011-1016.

Cao T, Shannon M, Handel MA \& Etkin LD 1996 Mouse ret finger protein (rfp) proto-oncogene is expressed at specific stages of mouse spermatogenesis. Developmental Genetics 19 309-320.

Creemers LB, Meng X, Den Ouden K, Van Pelt AM, Izadyar F, Santoro M, Sariola H \& De Rooij DG 2002 Transplantation of germ cells from glial cell line-derived neurotropic factor-overexpressing mice to host testes depleted of endogenous spermatogenesis by fractionated irradiation. Biology of Reproduction 66 1579-1584.

Davidoff MS, Middendorff R, Koeva Y, Pusch W, Jezek D \& Muller D 2001 Glial cell line-derived neurotropic factor (GDNF) and its receptors GFRalpha-1 and GFRalpha-2 in the human testis. Italian Journal of Anatomy and Embryology 106 173-180.

Dettin L, Ravindranath N, Hofmann MC \& Dym M 2003 Morphological characterization of the spermatogonial subtypes in the neonatal mouse testis. Biology of Reproduction 69 1565-1571.

Du Y \& Dreyfus CF 2002 Oligodendrocytes as providers of growth factors. Journal of Neuroscience Research 68 647-654.

Dym M, Jia MC, Dirami G, Price JM, Rabin SJ, Mocchetti I \& Ravindranath N 1995 Expression of c-kit receptor and its autophosphorylation in immature rat type A spermatogonia. Biology of Reproduction 52 8-19.
Franke WW, Grund C \& Schmid E 1979 Intermediate-sized filaments present in Sertoli cells are of the vimentin type. European Journal of Cell Biology 19 269-275.

Godet M, Thomas A, Rudkin BB \& Durand P 2000 Developmental changes in cyclin B1 and cyclin-dependent kinase 1 (CDK1) levels in the different populations of spermatogenic cells of the post-natal rat testis. European Journal of Cell Biology 79 816-823.

Godet M, Damestoy A, Mouradian S, Rudkin BB \& Durand P 2004 Key role for cyclin-dependent kinases in the first and second meiotic divisions of rat spermatocytes. Biology of Reproduction 70 1147-1152.

Heuckeroth RO, Lampe PA, Johnson EM \& Milbrandt J 1988 Neurturin and GDNF promote proliferation and survival of enteric neuron and glial progenitors in vitro. Developmental Biology 200 116-129.

Hofmann MC, Braydich-Stolle L \& Dym M 2005 Isolation of male germ-line stem cells; influence of GDNF. Developmental Biology 279 114-124.

Hu J, Shima H \& Nakagawa H 1999 Glial cell line-derived neurotropic factor stimulates Sertoli cell proliferation in the early postnatal period of rat testis development. Endocrinology 140 3416-3421.

Huckins C 1971 The spermatogonial stem cell population in adult rats, I. Their morphology, proliferation and maturation. Anatomical Record 169 533-557.

Hue D, Staub C, Perrard-Sapori MH, Weiss M, Nicolle JC, Vigier M \& Durand P 1998 Meiotic differentiation of germinal cells in three-week cultures of whole cell population from rat seminiferous tubules. Biology of Reproduction 59 379-387.

Jahnukainen K, Chrysis D, Hou M, Parvinen M, Eksborg S \& Söder O 2004 Increased apoptosis occurring during the first wave of spermatogenesis is stage-specific and primarily affects midpachytene spermatocytes in the rat testis. Biology of Reproduction 70 290-296.

Jing S, Wen D, Yu Y, Holst PL, Luo Y, Fang M, Tamir R, Antonio L, Hu Z, Cupples R et al. 1996 GDNF-induced activation of the ret protein tyrosine kinase is mediated by GDNFR-alpha, a novel receptor for GDNF. Cell 85 1113-1124.

Kamatsu-Shinohara M, Ogonuki N, Inoue K, Miki H, Ogura A, Toyokuni S \& Shinohara T 2003 Long-term proliferation in culture and germline transmission of mouse male germline stem cells. Biology of Reproduction 69 612-616.

Karlsson M, Lindqvist N, Mayordomo R \& Hallbook F 2002 Overlapping and specific patterns of GDNF, c-ret and GFR alpha mRNA expression in the developing chicken retina. Mechanisms of Development 114 161-165.

Kopecky M, Semecky V \& Nachtigal P 2005 Vimentin expression during altered spermatogenesis in rats. Acta Histochemica 107 279-289.

Kubota H, Avarbock MR \& Brinster RL 2004a Growth factors essential for self-renewal and expansion of mouse spermatogonial stem cells. PNAS 101 16489-16494.

Kubota H, Avarbock MR \& Brinster RL 2004b Culture conditions and single growth factors affect fate determination of mouse spermatogonial stem cells. Biology of Reproduction 71 722-731.

Laemmli UK 1970 Cleavage of structural proteins during the assembly of the head of bacteriophage T4. Nature 227 680-685.

Lin LF, Doherty DH, Lile JD, Bektesh S \& Collins F 1993 GDNF: a glial cell line-derived neurotropic factor for midbrain dopaminergic neurons. Science $2601130-1132$.

Linnarsson S, Mikaels A, Baudet C \& Ernfors P 2001 Activation by GDNF of a transcriptional program repressing neurite growth in dorsal root ganglia. PNAS 98 14681-14686.

Matsuo A, Nakamura S \& Akiguchi I 2000 Immunohistochemical localization of glial cell line-derived neurotropic factor family receptor alpha-1 in the rat brain: confirmation of expression in various neuronal systems. Brain Research 859 57-71.

Meng X, Lindahl M, Hyvonen ME, Parvinen M, De Rooij DG, Hess MW, Raatikainen-Ahokas A, Sainio K, Rauvala H, Lakso M et al. 2000 Regulation of cell fate decision of undifferentiated spermatogonia by GDNF. Science 287 1489-1493.

Meng X, De Rooij DG, Westerdahl K, Saarma M \& Sariola H 2001 Promotion of seminomatous tumors by targeted overexpression of glial cell line-derived neurotropic factor in mouse testis. Cancer Research 61 3267-3271. 
Nagano M, Avarbock MR, Leonida EB, Brinster CJ \& Brinster RL 1998 Culture of mouse spermatogonial stem cells. Tissue and Cell 30 389-397.

Nagano M, Brinster CJ, Orwig KE, Ryu BY, Avarbock MR \& Brinster RL 2001 Transgenic mice produced by retroviral transduction of male germline stem cells. PNAS 98 13090-13095.

Nagano M, Ryu BY, Brinster CJ, Avarbock MR \& Brinster RL 2003 Maintenance of mouse male germ line stem cells in vitro. Biology of Reproduction 68 2207-2214.

Oatley JM, Reeves JJ \& McLean DJ 2004 Biological activity of cryopreserved bovine spermatogonial stem cells during in vitro culture. Biology of Reproduction 71 942-947.

Onoda M, Djakiew D \& Papadopoulos V 1991 Pachytene spermatocytes regulate the secretion of Sertoli cell protein(s) which stimulate Leydig cell steroidogenesis. Molecular and Cellular Endocrinology 77 207-216.

Orwig KE, Avarbock MR \& Brinster RL 2002 Retrovirus-mediated modification of male germline stem cells in rats. Biology of Reproduction 67 874-879.

Parvinen M \& Ventela S 1999 Local regulation of spermatogenesis: a living cell approach. Human Fertility 2 138-142.

Pelet A, Geneste O, Edery P, Pasini A, Chappuis S, Atti T, Munnich A, Lenoir G, Lyonnet S \& Billaud M 1998 Various mechanisms cause RET-mediated signaling defects in Hirschsprung's disease. Journal of Clinical Investigation 101 1415-1423.

Perrard MH, Hue D, Staub C, LeVern Y, Kerboeuf D \& Durand P 2003 Development of the meiotic step in testes of pubertal rats: comparison between the in vivo situation and under in vitro conditions. Molecular Reproduction and Develoment 65 86-95.

Powers JF, Tsokas P \& Tischler AS 1998 The ret-activating ligand GDNF is differentiative and not mitogenic for normal and neoplastic human chromaffin cells in vitro. Endocrine Pathology 9 325-331.

Powers JF, Schelling KH \& Tischler AS 2001 Chromaffin cell mitogenesis by neurturin and glial cell line-derived neurotropic factor. Neuroscience 108 341-349.

Ribchester RR, Thomson D, Haddow LJ \& Ushkaryov YA 1998 Enhancement of spontaneous transmitter release at neonatal mouse neuromuscular junctions by the glial cell line-derived neurotrophic factor (GDNF). Journal of Physiology 512 635-641.

Russell LD, Alger LE \& Nequin LG 1987 Hormonal control of pubertal spermatogenesis. Endocrinology 120 1615-1632.

Ryu BY, Orwig KE, Avarbock MR \& Brinster RL 2003 Stem cell and niche development in the postnatal rat testis. Developmental Biology 263 253-263.

Ryu BY, Kubota H, Avarbock MR \& Brinster RL 2005 Conservation of spermatogonial cell self-renewal signaling between mouse and rat. PNAS 102 14302-14307.

Schlatt S, Zhengwei Y, Meehan T, De Kretser DM \& Loveland KL 1999 Application of morphometric techniques to postnatal rat testes in organ culture: insights into testis growth. Cell and Tissue Research 298 335-343.

Staub C, Hue D, Nicolle JC, Perrard-Sapori MH, Segretain D \& Durand P 2000 The whole meiotic process can occur in vitro in untransformed rat spermatogenic cells. Experimental Cell Research 260 85-95.
Steinberger A \& Steinberger E 1971 Replication pattern of Sertoli cells in maturing rat testis in vivo and in organ culture. Biology of Reproduction 4 84-87. Steinberger A \& Steinberger E 1977 The Sertoli cells. In The Testis, pp 371-399. Eds AD Johnson \& WR Gomes. New York, NY, USA: Academic Press. Suter L, Koch E, Bechter R \& Bobadilla M 1997 Three-parameter flow cytometric analysis of rat spermatogenesis. Cytometry 127 161-168.

Suter-Crazzolara C \& Unsicker K 1994 GDNF is expressed in two forms in many tissues outside the CNS. Neuroreport 5 2486-2488.

Suvanto P, Hiltunen JO, Arumae U, Moshnyakov M, Sariola H, Sainio K \& Saarma M 1996 Localization of glial cell line-derived neurotropic factor (GDNF) mRNA in embryonic rat by in situ hybridization. European Journal of Neurosciences $\mathbf{8}$ 816-822.

Tadokoro Y, Yomogida K, Ohta H, Tohda A \& Nishimune Y 2002 Homeostatic regulation of germinal stem cell proliferation by the GDNF/FSH pathway. Mechanisms of Development 113 29-39.

Trupp M, Ryden M, Jornvall H, Funakoshi H, Timmusk T, Arenas E \& Ibanez CF 1995 Peripheral expression and biological activities of GDNF, a new neurotropic factor for avian and mammalian peripheral neurons. Journal of Cell Biology 130 137-148.

Urbano AG, Suarez-Penaranda JM, Dieguez C \& Alvarez CV 2000 GDNF and RET-gene expression in anterior pituitary-cell types. Endocrinology 141 1893-1896.

Viglietto G, Dolci S, Bruni PB, Baldassarre G, Chiariotti L, Melillo RM, Salvatore G, Chiapetta G, Sferratore F, Fusco A \& Santoro M 2000 Glial cell line-derived neutrotropic factor and neurturin can act as paracrine growth factors stimulating DNA synthesis of Ret-expressing spermatogonia. International Journal of Oncology 16 689-694.

Wang Y, Chang CF, Morales M, Chiang YH \& Hoffer J 2002 Protective effects of glial cell line-derived neurotropic factor in ischemic brain injury. Annals of the New York Academy of Sciences 962 423-437.

Weiss M, Vigier M, Hue D, Perrard-Sapori MH, Marret C, Avallet O \& Durand P 1997 Pre- and postmeiotic expression of male germ cell-specific genes throughout 2 -week cocultures of rat germinal and Sertoli cells. Biology of Reproduction 57 68-76.

Yomogida K, Yagura Y \& Nishimune Y 2003 Dramatic expansion of germinal stem cells by ectopically expressed human glial cell line-derived neurotropic factor in mouse Sertoli cells. Biology of Reproduction 69 1303-1307.

Yu Y, Guo R, Ge Y, Ma J, Guan J, Li S, Sun X, Xue S \& Han D 2003 Gene expression profiles in different stages of mouse spermatogenic cells during spermatogenesis. Biology of Reproduction 69 37-47.

Received 16 December 2005

Received in final form 27 March 2006

Accepted 12 April 2006

Made available online as an Accepted Preprint 27 March 2006 